\title{
BADARASHMA PISHTI - AN OVERVIEW
}

\author{
Dr. Ravindra. G. \\ Varma* \\ Ph.D Scholar,Department of Shalya Tantra, Ayurveda Mahavidyalaya \\ Hubli Karnataka. *Corresponding Author

\section{Dr. S. K. Bannigol} \\ Principal, Sanjeevini Ayurvedic Medical College, Hubli, Karnataka, India
}

ABSTRACT Badarashma resembles like a fruit of Badara. Pishti is also known as Sange Yahood Pishti, Ber Pathar Pishti, lime Silicate. It is a fossilized stone primarily containing silicate of lime. Aging increases the risk of urinary disorders, especially after 5th decade. Lower urinary tract symptoms are more prevalent among the elderly and various clinical studies have also demonstrated advancing age to be associated with a reduced bladder capacity, increase in prostate size which ultimately leads to increase in uninhibited contractions, decreased urinary flow rate, diminished urethral pressure, increased post voidal residual urine volume and many a times lower urinary tract symptoms also. There are so many Ayurvedic drugs which have proven to be the best. Badarashma Pisthi is a comprehensive natural remedy for any kind of urinary obstruction or any other urinary disorders. The main health and therapeutic properties of Badarashma Pisthi is diuretic, lithotriptic and analgesic.

\section{KEYWORDS :Hazrool Yahood, Badarashma Pisthi, Urinary Disorders.}

\section{INTRODUCTION:}

Ayurveda is the science of life which deals with maintenance of health and cure of disease. The term drug is derived from a French word "Drouge" means a dry herb. In Ayurveda, the word "Aushadha" or "Dravya" is used as a synonym of drug. In Ayurvedic classics Aushadha is considered one Pada among the Chikitsa Chatuspada ${ }^{1}$. The consideration of recipes during the line of treatment for particular ailment has a great importance. In the modern era, W.H.O. also stresses the importance of drugs and defines it as a substance or product that is used or intended to be used to modify or explore physiological system or pathological status for the benefit of the recipient. Ayurveda was the first to give an elaborate description of various therapeutic measures calculated to aim at, not merely of radical removal of the causative factors but also at the restoration of doshika equilibrium ${ }^{2}$.

According to Ayurveda, drug or diet article that revise or break the Samprapti is without producing any side effect has been look upon as ideal drug or diet. Ayurvedic treatises speak about the importance of drug as "Nothing in the world exist which does not have therapeutic utility. In Charak Samhita Sutra sthana Acharya Charaka states that "A potent poison also becomes the best drug on proper administration on the contrary even the best drug becomes a potent poison if used improperly". Taking this fact into consideration Ayurvedic physician have formulated single as well as compound drugs for the cure as well as the prevention of various ailments.

\section{BADRASHMA:}

The drug is not found to be explained in any of the Ayurvedic classical texts. Therefore the Vyutpatti is not found in the Ayurvedic classical texts. The drug is borrowed from Unani texts and given the name Badarashma. The name is derived so because, it resembles like that of the fruit of Badara well said in Ayurveda. The column and shape are similar. The only difference is, Badarashma is not a plant origin but derived from Asthma (Stone).

\section{Badara: Means Badara phalvat and size}

Asma : Means hard and derived from stone

Hence, the name Badarashma means like that of Badaraphala, originated from fossil stone.
VERNACULAR NAMES ${ }^{3}$ :

\begin{tabular}{|l|l|l|}
\hline 1 & Hindi & Ber Pathar, Pathar Ber, Hazart Ber \\
\hline 2 & Gujarati & Hazarat Bora \\
\hline 3 & Pharsi & Hajrul yahud \\
\hline 4 & Arabi & Yahud, Hajrujiaitun \\
\hline 5 & English & Fossile encrinites \\
\hline 6 & Sanskrit & Badarashma \\
\hline
\end{tabular}

Part used: Stony growth

\section{History:}

- Badarashma is not referred in Samhitas, Sangraha and Nighantus.

- Badarashma is originally from Unani and is followed by the modern time scholars.

- It was firstly described by Acharya Yadavaji's in his text Rasamruta.

- It is a stone similar to the fruits of jujube having an oval shape and pointed ends. It is brownish from out-side and greenish white from inside. Its size is 1 to $1 / 2$ inch. It does not have any taste. It can be pasted with water easily. It is a compound of silica and lime. It is imported from Arab countries to India and commonly used by Unani physicians.

\section{Occurrence and origin:}

In olden times, a worm which resembles cylindrical in shape, when dies it might have transformed into a hard mass due to the chemical to the composition of Calcium Silicate, means the Calcification of the fossil sea worm. The shape resembles cylindrical, broader at base and constricted at the tip, externally having folds and layers. Currently the drug is borrowed from the Arabian coastal areas, which is obtained in between the sea shore stones.

Chemical Composition:

Chemically Badarashma is a combination of Calcium and Silica, called Silicate of lime (Rasamruta) ${ }^{4}$ \& Calcium silicate (P.V.Sharma) $)^{5}$

Rasapanchaka:

\begin{tabular}{|l|l|}
\hline Rasa & Madhura, Kashaya \\
\hline Guna & Guru, Sheeta, Slakshana, Sukshma \\
\hline Virya & Sheeta \\
\hline Vipaka & Madhura \\
\hline Doshaghnata & Trishosghna \\
\hline
\end{tabular}


Method of Badarashma Pishti Preparation:

Samanaya Badarashma Shodhan ${ }^{6}$ :

Badarashma was thoroughly washed in jala and dried; the process was continued for 3 times. By this the physical impurities are removed.

\section{Vishesha Shodhana:}

Badarashma was kept on fire, until it becomes red hot and then immersed in Mulaka swarasa. This process is repeated for 7 times.

\section{Badarashma Pishti Nirmana:}

Its Pishti was prepared by grinding it with Gulab arka for 3days.

\section{Procedure?:}

Shodhita Badarashma was taken in a clean dry khalva yantra, sufficient quantity of gulab arka was added and mardana was carried out for 3 days and pishti was prepared from it. During procedure one must take care that Mardana should be done slowly and carefully to avoid spillage and wastage. The pressure during mardana should be uniform. Direction of rotation during mardana should be kept constant throughout the process. Prepared Badarashma Pishti can be filled in $250 \mathrm{mg}, 500 \mathrm{mg}$ of capsules.

\section{Karmukta:}

Mutrala, Pittashamak, Ashmarisulahar, Ashmari-Sarkara Rechack, Antispasmodic, Lithotriptic , Analgesic.

\section{CONCLUSION:}

Badarashma though it is originally belongs to Unani medicine, but in Ayurveda first time Vaidya Yadavaji explained in his text Rasamurta and Badarashma has mainly having action on mutra vaha sroto vikaras. Now it is becoming more familiar in the field of Ayurveda.

\section{REFERENCES:}

1) Vaidya Jadavaji Trikamji acharya edited Charaka samhita Sutrasthana -9/3, edition reprint 2009, and pub: Chowkhamba surabharati prakashana Varanasi, pg-61.

2) Vaidya Jadavaji Trikamji acharya edited Sushruta samhita Sutrasthana15/43, edition reprint 2010, and pub: Chowkhamba surabharati prakashana Varanasi, pg- 75 .

3) Swami Krishnanad ji edited Rasatantrasaar \& Siddhaprayog Sangraha Pratham khanda Bhasma prakaran, 14th edition 1999, pub: Krishna gopal Ayurveda Bhavanam Ajmer, pg 218

4) Achary Yadavji Trikamji, edited -Rasamritam, Chapter 3, Shloka -34, lst Edition, 1998 Choukambha Sanskrita Sansthana, Varanasi, Page no. 126.

5) Acharya Priyavrut Sharma edited Priya Nighantu chapter 6 Suvarnaadi varga, edition 2nd, pub: Choukambha Sanskrita pratishthan Delhi, pg 157.

6) Prof. Siddhanandan Mishara edited Ayurvediya Rasashastra Badarashma, 13th edition 2003, pub: Chowkhamba Orientalia Varanasi, pg- 696.

7) Prof. Siddhanandan Mishara edited Ayurvediya Rasashastra Badarashma, 13th edition 2003, pub: Chowkhamba Orientalia Varanasi, pg- 697. 